\title{
ARTICLE \\ Study the Role of Maritime Energy Management in Achieving the United Nations Sustainable Development Goals (UN SDGs), in partic- ular, Goal 7, in Oman Maritime Community
}

\author{
Hamid Reza Soltani Motlagh* \\ Department of Maritime Engineering, International Maritime College of Oman (IMCO), Suhar, Oman
}

\begin{tabular}{l} 
ARTICLE INFO \\
Article history \\
Received: 21 December 202 \\
Accepted: 15 March 2021 \\
Published Online: 30 March \\
\hline Keywords: \\
Sustainable development \\
Maritime energy \\
Maritime community \\
Oman maritime \\
Energy management \\
UNSDGS \\
Development goals
\end{tabular}

\section{Introduction}

In 2015, the UN General Assembly issued a strategic document called the Sustainable Development Goals-Agenda 2030, and the member states committed to doing it. This document contains 17 essential goals for sustainable development in different fields with the same approach and the goal ${ }^{[31]}$.

These 17 goals, along with 169 related targets, encompass three key areas, including environmental, economic, and social, that significantly impact the planet and humanity as vital issues ${ }^{[31]}$. According to the agenda 2030,

\begin{abstract}
Sustainability is a concept for achieving integration and balance in development to preserve and use resources properly by providing new solutions to overcome structural, social and economic misconceptions to prevent further degradation and waste of natural resources and create a better future for human societies. Sustainable development can be defined as a strategy for the correct use of resources, by modifying and redefining consumption patterns and avoiding one-sided development approaches. Therefore, sustainable development is defined as a long-term and unlimited solution for aligning different concepts (social, economic, and environmental), seemingly independent but related and influencing each other. This paper examines the challenges and capacities of the Oman Maritime Community and Maritime Energy Management's role in terms of sustainable development. To analyze this issue, the role of key players in Oman's maritime industry, such as the Oman Fisheries Company and the Oman Shipping Company, has been studied with the five main indicators of sustainable development goals, including people, the planet, peace, welfare, and partnership.
\end{abstract}

all countries are determined and undertake to provide and design a roadmap and plan of action on ending poverty and hunger of the people, protect the planet, prosperity for humanity, peace and mobilize resources for the implementation of the objectives of the Global Partnership on What is stated in the Sustainable Development Goals.

The most important factor for achieving these goals is the determination and responsibility of all people and all stakeholders and industries to achieve them. The maritime industry is one of the main players in achieving these goals. The responsibility of all people, stakeholders, and

*Corresponding Author:

Hamid Reza Soltani Motlagh,

Department of Maritime Engineering, International Maritime College of Oman (IMCO), Suhar, Oman;

Email:hamid@imco.edu.om 
industries to achieve these goals. The maritime industry is one of the main players in achieving these goals.

Therefore, as the industry's principal source, the International Maritime Organization (IMO) has issued and clarified the necessary roadmaps and guidelines in all areas relevant to these goals for sustainable development ${ }^{[8]}$. Among these areas is the topic of energy and its management, as identified in goal number seven and has been addressed.

Therefore, the International Maritime Organization, in the field of energy and its management, focuses on facilitating international cooperation and global partnerships for the deployment and access to modern, sustainable, and affordable energy in the maritime industry, which is mentioned as the Global Maritime Energy Efficiency Partnerships Project (GloMEEP) and being implemented in partnership with the United Nations Development Programme (UNDP), Global Environment Facility (GEF) and IMO ${ }^{[8]}$.

The project aims to provide a platform and a framework to build the capacity needed to increase energy efficiency and enhance marine energy management by increasing participation at national, regional, and global levels, focusing on developing countries ${ }^{[8]}$.

Another important project, which IMO is currently undertaking is the Global Maritime Technology Cooperation Center (MTCC) Network (GMN) that focuses on mitigating the impact of the maritime industry on climate change and providing technical solutions to developing and less developed countries ${ }^{[4]}$.

The Maersk shipping company has defined the company's position and responsibility for each of the sustainable development goals and the type of impact those goals have, on the company's goals and vision ${ }^{[12]}$.

In 2019, for example, five Pacific states entered into a treaty that would emit greenhouse gas emissions from the ship's fuel consumption. In the first phase, and by 2030 , it has reduced by 40 percent, and by 2050, it will reach zero ${ }^{[32]}$. Another example is The Blue Generation Project, which is currently underway in the European economic area and aims to create sustainable employment for young people without a job ${ }^{[1]}$.

This paper examines Oman's maritime industry and its maritime energy management role in achieving sustainable development goals, with a particular view to goal seven on energy and energy management.

\section{Literature Review- Maritime Industries and SDGs}

In a study on the maritime industry's role in achieving the goals of sustainable development, five areas have been mentioned as opportunities. All sustainable development goals are within the scope of these opportunities and include the Paris Agreement, sustainable infrastructure, ocean life protection, sustainable ocean economies in the future, and accountability for practical action in this $\operatorname{area}^{[3]}$.

In energy, which is defined under goal 7, the development and implementation of methods to reduce greenhouse gas emissions on ships and other marine industries are emphasized through supportive strategies, development of standards, and financial incentives. Also, the extraction of energy from oceanic resources or available in the oceans with the aim of sustainability in the ocean economics is one of the opportunities expressed in this study ${ }^{[3]}$.

A research on the shipping industry's effectiveness shows that in viewpoint of the type and intensity of the effect, very directly and with high impact, shipping can affect goals 7 and 13 related to clean energy and climate action, respectively. The effects of shipping on other targets are moderately direct or indirect, with moderate to low intensity. On this basis, shipping can help renewable energy by creating the necessary platform and providing support and technical services, for the extraction, harvesting and distribution of this type of energy ${ }^{[3]}$.

Moving to alternative fuels with zero emissions, using renewable energy, or improving energy efficiency, and providing a platform for developing innovative methods in all ship operations, are other things that can be considered in terms of achieving sustainable Shipping and fulfillment of agenda 2030. Looking at the global shipping fleet in regard of number, the effectiveness of implementing strategies related to renewable energy can be very high in achieving the targets set in Goal $7^{[3]}$.

Maritime industry can play a key role in this by synergizing partnerships with the public, private sectors, other industries and its powerful IMO (International Maritime Organization) platform. Besides, the maritime industry can take effective steps towards achieving Goal 17 by exchanging experiences and technical knowledge in various fields and participating in developing strategies and roadmaps for sustainable development ${ }^{[3]}$.

Another study points out the limitations that researchers face in examining the maritime industry's current position concerning the current situation and the vision of sustainable development goals. Lack of access to information from many private shipping companies, providing various interpretations and interpretations of Goal 10 as reducing inequality, are among these limitations. As this study emphasizes the fundamental role of the shipping and maritime industry in reducing inequality by increas- 
ing and expanding access to logistics resources, it points to further research on the role of shipping and logistics in Goal $10^{[33]}$.

According to this study, most of the information used in the analysis of the current situation and the maritime industry's interaction with the agenda 2030 has been done generally and mainly based on the data of container companies or liner lines. Accordingly, although container companies account for a large volume of global Shipping, they may not fully reflect other actors' conditions in the field of maritime transport ${ }^{[33]}$.

By defining the concept of sustainable Shipping, the International Maritime Organization has identified areas in which the maritime industry can assist and support the implementation and achievement of each of the sustainable development goals and, ultimately, the achievement of a sustainable planet. IMO plays an irreplaceable role in facilitating global trade by providing a suitable platform for cooperation and participation of all countries in maritime transport, as the least expensive transportation method with the most efficient energy consumption. According to this approach, sustainable and secure maritime transport is one of the main pillars of sustainable development with a poverty reduction approach by providing access to basic goods for nations ${ }^{[8]}$.

One of the major threats to food security and achieving a sustainable food chain is illegal fishing. Since fish is one of the main sources of food for most people globally, illegal fishing is an important obstacle to ending hunger, a serious threat to the protection and sustainability of the marine environment, and the livelihood of fishermen who work legally ${ }^{[8]}$.

The formulation and implementation of laws to reduce the emission of harmful gases is another IMO move that is taken to achieve a sustainable environment and is very effective and vital for communities' well-being, especially in coastal areas and cities. One of these decisions is implementing the Convention on the Reduction of Sulfur in the Fuel Oil Consumption of Ships, which has been implemented since the beginning of 2020 and has affected the health and lives of coastal residents through environmental protection ${ }^{[8]}$.

Since achieving the concept of sustainability in all its dimensions requires comprehensive education by providing equal opportunities for all nations of the world, the IMO also develops the necessary standards in the form of an international convention on seafarers' training, not only added on transport safety marine but also in all stages of training, it has emphasized on environmental protection and safety at sea ${ }^{[8]}$.

From the perspective of gender equality in education, the IMO view is formed to provide job opportunities by empowering and facilitating education for women. The IMO believes that women's activities alongside men in various maritime industry sectors contribute to the development, productivity, and economic growth of communities ${ }^{[8]}$

Due to fact that achieving a sustainable society without access to clean water and sanitation, as the most vital element of human needs, is difficult or impossible, the IMO has emphasized the management of ship waste and the prevention of waste disposal at sea, intending to preserve water resources and prevent water pollution. The London Convention can be considered the most effective IMO guideline that has been developed in this regard ${ }^{[8]}$.

One of the most important and effective IMO projects being implemented in partnership with the United Nations Development Program and the Global Environment Facility is to focus on the participation of all countries and the use of all regional and trans-regional capacities for marine energy efficiency, and supports carbonation programs and companies active in this field ${ }^{[8]}$.

This capacity building, in addition to improving energy efficiency in the marine industry, is also emphasized in the Climate Mitigation program and is actively pursued and supported through various projects with the support of developing or less developed countries. . This support is provided through synergy and international partnership to facilitate access to new technologies in clean fuels, optimize energy consumption, attracting investment to develop energy infrastructure and transferring technical knowledge related to renewable energy ${ }^{[8]}$.

Providing job opportunities for sustainable economic growth is one of the IMO's focuses on achieving sustainable development goals. The need for seafarers is obvious as a basic element in the maritime industry. Attention to working and living conditions, social security, and their problems are at the forefront of what the IMO emphasizes $^{[8]}$.

IMO support for sustainable economic growth is not limited to the shipping sector. Participate in the development of port infrastructure, pay special attention to creative and innovative technologies, extract energy from marine resources, promote the maritime tourism industry, support fisheries and maritime security, among other IMO-supported sectors, in order to strengthen and contribute to economic growth all nations nationally, regionally and globally ${ }^{[8]}$.

Other global contributions that the IMO emphasizes in achieving the goals of sustainable development, and which has adopted an important strategy so far, are the development of protocols and implementing laws in various 
sectors of the maritime industry to reduce greenhouse gas emissions, and support Practical and ambitious methods in stopping and combating climate change caused by the maritime industry ${ }^{[8]}$.

Protecting the resources of the oceans and seas, through conventions related to the prohibition of waste disposal at sea, noise pollution caused by ships traffic, preventing the transfer of harmful marine organisms by the water of ballast tanks of ships, and improving the safety and quality of shipbuilding and navigation are other important issues that the IMO is committed to, as the highest decision-maker in the maritime industry ${ }^{[8]}$.

Contributing to the development of maritime education institutions, to strengthen the scientific strength of countries and prepare regulatory regimes on shipping issues by training experts in this field is another support coverage that the IMO is committed to and knows it an important part of the sustainable development process with the approach of peaceful development of societies ${ }^{[8]}$.

IMO's extensive cooperation with a wide range of projects, the private sector, and environmental centers, has the potential to enable this international organization to achieve the goals of sustainable development and the development of innovative methods, both in education and in the fields of provides design, construction, the safety of ships and optimization of ships' energy consumption ${ }^{[8]}$.

A research published by the European Commission on sustainable maritime transport with an environmentally friendly approach to port activities emphasized the need to encourage operators who meet approved environmental standards in all their activities to reduce greenhouse gas emissions and energy optimization. According to this plan, which has been implemented in many European ports since 2011, ships that use methods and fuels to reduce emissions can pay lower port costs as a reward ${ }^{[5]}$.

In a study in Norway, it has been pointed out the importance of governments' role through the actions of sustainable development in the maritime industry. According to this research, the government can achieve sustainable development goals by formulating specific programs and strategies and investing in infrastructure based on the development of zero-emission solutions in the maritime industry, with a special look at Innovative Solutions ${ }^{[10]}$.

Intelligent transportation, automated ships, and the use of alternative fuels, such as hydrogen, biogas, battery, and natural gas, are among the possible solutions in this study. Also, synergism in the participation of public and private sectors, by providing a suitable platform for research on creative projects, using research and training institutions' capacity, can accelerate this process ${ }^{[10]}$.

As one of the most important companies in the field of maritime transport, Maersk Shipping Company intends to reduce its carbon dioxide emissions by $60 \%$ in 2030 compared to 2008 and onwards, reduce gas emissions to zero by 2050 . To achieve this strategy, Maersk focuses on working with all stakeholders to develop the policy and framework needed to achieve this goal and sustainable shipping in line with the goals of sustainable development $^{[11]}$

In line with sustainable development goals in terms of economic growth and environmental protection, Maersk Company is moving in the direction of active participation through investment and creating opportunities in the ship recycling industry in its organizational strategy. Reducing inequality by providing the same job opportunities by creating an inclusive culture, along with gender diversity at different organizational levels, is a key element in the company's commitment to achieving sustainable shipping $^{[11]}$.

The installation of scrubbers system in the company's fleet and the use of fuel with low sulfur content have been done according to international laws and to reduce air emissions. In this direction, the company is actively involved in meeting the goals of sustainable development in human health and environmental protection by investing and supporting solutions to reduce air emissions ${ }^{[11]}$.

Preserving the oceans' health and life as a great natural heritage for human beings is another issue of concern to this company. The importance of the seas' life is so vital that a large part of this important human resource in providing a livelihood for the people of the world is exposed to various threats from various aspects ${ }^{[1]}$.

The most critical threats to marine life, which is growing at an alarming rate, is the influx of large amounts of plastic waste into the seas. Strict implementation of regional and international guidelines regarding ballast water and waste management system, support, and close cooperation with companies active in ocean cleaning and ocean science research centers is what Maersk company pursues the health of the seas ${ }^{[1]]}$.

Free transportation for health services, with the support of Mercy Ships, for sustainable welfare and health, reducing economic gaps, and providing a platform for underdeveloped countries, is an approach taken by the Mediterranean Shipping Company as part of its sustainable development goals. Providing voluntary logistics services, financial support, and voluntary services in various fields, in natural disasters in different countries, and across borders are other supports that this company provides along the sustainable development path ${ }^{[14]}$.

Gender equality in order to eliminate discrimination and create equal opportunities for women in various sec- 
tors related to the company's activities is also emphasized in the company's annual report on sustainable maritime transport ${ }^{[14]}$.

Important decisions and programs identified in the MSC Annual Report include partnership in the development of the ship recycling industry, improving waste management, minimizing the destructive environmental impacts caused by this industry,improving the quality of workers' education, and pay attention to health status. The continuous and sustainable staff training Program is another key and prominent item in its programs, including onboard staff and onshore personnel ${ }^{[14]}$.

Providing the necessary facilities for sustainable water management in various places and providing access to clean water by modern and reliable treatment systems are other projects that MSC has implemented in different parts of the world, and intends to develop and implement it elsewhere based on its sustainable development plan. Investment in robotics and automation in Antwerp's port to reduce emissions, installation and operation of wind turbines to generate electricity, optimize water consumption. Intelligent separation and recycling of waste in this port, are among the methods used to increase sustainability in the port, which is intended by the company ${ }^{[14]}$.

The challenge of climate change resulting from traditional transportation and finding solutions that can respond to climate change is another requirement for sustainable development that MSC has invested in. An example of this investment is in the installation of equipment and finite element modeling in container terminal cranes in some ports, which can lead to improved performance in a wider range of air temperature changes and increase the stability of cranes by installing water tanks in the lower part of the crane structure and thus reduce its center of gravity. These cases greatly help the crane structure resistance in bad weather conditions and natural disasters such as earthquakes and improve ports' sustainability ${ }^{[14]}$.

Utilizing of various technical solutions such as making changes and modifications in bow, rudder, and propeller, on-line and continuous monitoring of the ship's hull in terms of cleanliness, using anti-fouling paints, increasing the carrying capacity, installing the necessary equipment for cold-iron, the use of the air lubrication system is part of the measures that the company has taken to optimize energy consumption and reduce emissions in its active vessels and projects under construction ${ }^{[14]}$.

In 2018 , a program was formed to aim the synergy of global leadership to achieve sustainable development goals in collaboration with the International Association of Ports and Harbors and several major ports in different countries, known as The World Ports Sustainability Pro- gram (WPSP).In the energy and climate sectors, projects focus on creative projects to reduce ship emissions in ports, improve port operations, generate electricity from renewable sources, carbon capture methods, and the climate change approach ${ }^{[35]}$.

These projects' priorities are in port call optimization, providing low carbon fuel for ships and supplying electricity to ships from land through renewable energy sources to reduce greenhouse gases ${ }^{[35]}$.

In sustainable development goals related to gender equality, health, social responsibilities, and education, various projects are being implemented in ports or are about to be implemented. Allocate a portion of port revenue to develop coastal school infrastructure and improve the quality of health centers in the area, along with women's participation in the maritime industry to empower them, provide scholarships in areas related to port operations, and marine pilots are among the projects outlined in this report ${ }^{[35]}$.

Regarding environmentally friendly and resilient infrastructure, most projects for port sustainability are related to the use of information technology and intelligent systems in improving supply chain and port operations along with meeting the needs of the market and stakeholders through codified planning with a view to development. In this regard, the principle of flexibility in infrastructure development is very important, so that part of this development is related to environmental monitoring using digital methods. The other part is focused on the exchange of information between the port and stakeholders ${ }^{[35]}$.

Most of this program's projects are related to the interaction and development of communication between the port and neighboring cities, which is related to the environmental impacts and social interactions of the ports on the surrounding communities and requires effective communication and participation of both parties in sustainable development. This partnership and interaction are defined in the form of creative initiatives and projects that can meet the needs of the surrounding communities, such as the development of the local economy, the expansion of green areas, and investment in education ${ }^{[35]}$.

Also, environmental considerations arising from the existence of ports and port operations such as waste management, noise, and air pollution, conservation of water resources and ecosystems in the region, in addition to managing ports in accordance with the goals of sustainable development, is another aspect that has been considered in effective participation projects of ports and local communities ${ }^{[35]}$. 


\section{Oman Overview- People, Environment, and Economy}

Oman is located in Western Asia and has a coast to the north with the Gulf of Oman and the east by the Arabian Sea. Oman's coast reaches more than two thousand kilometers ${ }^{[20]}$. Oman's population in 2019 is estimated to be around five million, and it is projected to reach over five million by $2020^{[25]}$.

In the same year, most of the population is between 25 and 34 years old, whereas the number of males is twice that of females, and $60 \%$ of Oman's population are of working age ${ }^{[25]}$. In the environment, Oman has committed itself to protect the environment by joining almost all international treaties ${ }^{[2]}$. Oman also has a ministry of environment and climate affairs, which demonstrates the importance of the country's environment ${ }^{[16]}$.

Economically, according to the latest World Bank report, Oman has the highest economic growth in its region. The report expects growth to continue in the coming years with more investment in the upstream and infrastructure industries ${ }^{[30]}$.

\section{Background of Oman Maritime Communi- ty}

Oman has a long history of sailing and shipbuilding due to its long coastlines and is one of the leading countries in this industry. Oman's shipping dates back to over 4,500 years ago, which has been in contact with other countries worldwide, especially India and the countries of North and East Africa. The Omanis have been highly skilled in boat construction and maritime navigation with a well-known port in the world ${ }^{[15]}$.

Its background has long been active in two major maritime areas, namely maritime trade and fishing, and is still one of the most critical industries in the country even today. Archaeological findings at the ports of Oman, which include objects and equipment from China and other countries, indicate antiquity in the country's maritime sector carried out by Oman ships ${ }^{[13]}$.

With its long and significant coastlines, the fisheries sector, as an essential source of food supply, has a long history in the country that caters to local and regional needs ${ }^{[34]}$.

With the expansion of knowledge in the maritime industry, the country is active in other related industries, such as dry-dock, oceangoing ship repair and maintenance and passenger ferries, as well as in the field of maritime trade and fisheries.

In 1989, Oman set up the Oman Fisheries Company to take a significant step towards global markets. In this re- gard, Oman Fisheries Company established and launched six processing plants with the most advanced equipment and currently exports products to more than 55 countries $^{[21]}$.

Oman Shipping Company was established in 2003 to meet the rapidly evolving needs of the country's industries. With a fleet of natural gas vessels, large oil tankers, chemical tankers, bulk carriers, General Cargoes, and container carriers, the company plays a vital role in Shipping and development. The main approach and purpose of the company are to provide efficient and reliable services to national, regional, and global customers, taking into account the high level of standard and safety, while at the same time taking an exclusive look at environmental protection ${ }^{[26]}$.

One of the active industries in the Oman maritime industry is Oman Drydock, which was established in 2006 to promote modest industrial structure growth. Its services include repairing and converting large ships in various models and are also active in providing services to the oil, gas, and infrastructure industries ${ }^{[18][19]}$.

In passenger transport, the Oman National Ferries Company (NFC) started operating in 2006 to contribute to the promotion and development of maritime transport, especially in the domestic sectors, and to establish an effective connection between the country's ports ${ }^{[17]}$. The service provided by the company is not limited to passenger transport, and in addition to scheduled inter-port services, it has been providing dedicated trips since $2008^{[17]}$.

\section{Local Challenges and Needs}

To examine the challenges and needs of marine energy management with what is stated in the Sustainable Development Goals and goal 7, should first review the defined upstream documents and then review the documentation available in the Oman country.

The growing need and increasing demand for energy, as the driving force behind the development, along with population growth and the expansion of industries, are significant challenges in achieving sustainable development goals. This challenge is crucial in balanced growth, consistent and sustained management of the various sectors involved in energy development. Including the sections as follows:

1)Awareness of existing and potential resources.

2)Investigating and calculating the capacity of existing or available renewable and sustainable energy sources.

3)Finding practical and cost-effective solutions to optimally and efficiently use energy resources.

4)A clear plan and roadmap for developing the infrastructure needed in energy management in a coordinated 
and balanced manner.

5)Mobilizing existing national and international facilities for investment in energy infrastructure or optimizing the use of existing resources.

6)Human resources training, and skilled people, to manage energy or operate new systems.

7)Investing in research and development, in close cooperation with science and education communities and the industry with governments' participation to facilitate and accelerate it.

8)A passion and interest in applying innovative technologies and techniques with a positive attitude.

Increase partnerships at the national, regional, and international levels, for synergies, overcome the impediments and ultimately use the successful models and designs used in other countries to accelerate sustainable development.

The imbalance, and the uneven growth, in each of the above sectors can pose a new challenge to energy management. Instituting this global resolve, in the form of a national movement, and utilizing all available capacities to encourage and extend this approach through a targeted program in the organizational structure of education and country management, can be a constructive move towards sustainable development.

Other challenges include resistance from organizations or people to change behavior and consumption patterns due to lack of need, lack of transparency towards development goals, and lack of awareness of the need for energy management, low cost of energy consumption, lack of social accountability, in the public and community level ${ }^{[29]}$.

The high initial cost of investment in renewable energy production, especially in countries with oil and gas resources, and low energy prices reduce their tendency to use new energy ${ }^{[29]}$.

Another challenge is the lack of confidence in innovative and modern designs and methods, which create resistance and doubt in the industry body in applying new solutions. Many of these innovative designs and solutions are still in the pilot phase and require further research and development. Meanwhile, only a limited number of countries have done so.

In Oman, the Ministry of Transport and Communications (MOTC), as a standard and related reference, with the International Maritime Organization, and the Oman Maritime Industry, has been working on explaining and updating roadmaps and sustainable plans development goals ${ }^{[23]}$.

Time is also challenging. Over time, the amount of non-renewable and hydrocarbon fuels decreases every day, and their environmental effects deeper and last longer.
Regional threats, internal conflicts, insecurity, and instability of countries, which transmit a large part of countries' ability to cope with these threats, as well as increasing the riskiness of investing in the energy sector and thereby reducing or disabling them in attracting foreign or even domestic investment, is another challenge. Some countries' geographical location, sometimes even unintentionally, may affect these threats, even if they do not play a role in the threats.

The Oman Ministry of Transport and Communications' annual report, released in 2018, outlines the need for efficient and sustainable transport and the development of access at reasonable and cost-effective rates, as set out in the ministry's mission ${ }^{[23]}$.

Next much more comprehensive document on sustainable development goals is the 2019 Supreme Council for Planning (SCOP) report, which has done a thorough review of each of Oman's sustainable development goals.

The study emphasizes the need for all countries to meet and address challenges at the regional and global levels ${ }^{[28]}$. Among these challenges are fossil fuels and oil, which are essential and influential variables on the economy and global challenges such as the recession in the economy have also been mentioned. Population growth and changing population patterns towards a young and jobseeker are other challenges in the country ${ }^{[28]}$.

The critical programs in this field are optimizing and targeting budgets using energy-saving methods and looking at using environmentally friendly and sustainable models ${ }^{[28]}$. Changing the oil-based economic pattern, diversifying the economy, decreasing oil dependence and income to reduce the effects of oil prices are among the needs of target countries ${ }^{[28]}$.

Investment issues is other concern, especially the private sector, which was not acceptable due to some legal barriers. It needs laws and procedures that encourage the private sector to invest. The private sector is also one factor contributing to the reduction of unemployment and job opportunities, which is a severe and significant challenge for achieving development goals ${ }^{[31]}$.

Provide supportive policies to attract young people by the private sector or supporting young people to start a business is cited as a solution to this challenge. There is a need for stability in the economy and the growth and development of domestic production while creating new job opportunities and improving policies and laws to facilitate employment, including government goals and programs.

Another point is the training of the skilled workforce needed, given the market need and familiarity with the new technologies, which has led to the establishment of the National Youth Organization in Oman ${ }^{[28]}$. Oman is 
working to overcome the challenges of achieving goal 7 of Sustainable Development and moving towards renewable energy by developing a clear roadmap called the National Energy Strategy ${ }^{[28]}$.

These include a plan to reduce fifty percent of the gas used in the oil industry and use solar energy as an alternative and sustainable energy by the beginning of $2026^{[28]}$. Other challenging energy topics, the existence, and stability of government subsidies and support, access to gas as an energy source, population growth as a consequence of the growth of energy consumption, and ultimately, the growth and development of industries and increasing energy demand ${ }^{[28]}$.

Regarding renewable energy, this technology's continued use remains a significant challenge, and besides raising professional people who can respond to this new model of energy. Instance of these projects are the "Mirra" project, which has replaced gas consumption in one of the Oman oil fields by using solar power generation and generating more than 1,000 megawatts of electricity ${ }^{[28]}$.

Oman, given the International Maritime Organization's acceptance of its regulations, as its principal source of industry, is bound to enforce these rules. Therefore, it can be said that the implementation and adherence to these laws and guidelines are in line with the goals of sustainable development.

Including these rules and regulations are guidelines for the Ship Energy Efficiency Management Plan (SEEMP) to reduce fuel consumption and reduce pollution ${ }^{[7]}$. Besides, guidelines for the Energy Efficiency Design Index (EEDI) required for the construction of new vessels are also included in the plans used for marine energy management ${ }^{[7]}$.

In 2019, the Oman Shipping Company ordered the construction of three very large oil tanker vessels at the Daewoo Shipbuilding Company in South Korea. Important and essential in this order is the eco-friendliness of these ships and the new generation of this class of ships ${ }^{[24]}$.

In the matter of ships and vessels other than those required by the IMO guidelines, and shipping companies required to implement it, no report or solution was found, especially on renewable energy use. In 2019, an international conference on marine engineering and technology was organized by the Oman Military College of Technology. It covered various chapters, including optimizing fuel consumption and using renewable energy in the maritime industry ${ }^{[6]}$.

Such approaches can, in addition to driving existing national and international capacities toward an acquaintance with modern knowledge or innovative designs and solutions, plays a vital role in the synergies and active partnerships between the various sectors of the industry, especially in relation to scientific and industrial centers, and in line with development goals.

Concerning the training of expert and knowledgeable staff, familiar with the issues of energy management, the Ministry of Transport and Communications of Oman has emphasized that the manner of issuance of documents is based on Seafarers' Training, Certification and Watchkeeping standards and as a result, people should be thoroughly familiar with the rules and guidelines of the International Maritime Organization, including the objectives of sustainable development, increasing efficiency, and energy management ${ }^{[23]}$.

It seems that professional development is not limited to people working in the fleet.

About energy management, there is also a need for people capable of policy and decision making and be familiar with economic, environmental issues and safety, requiring a plan to train these people and to use them to improve energy management and energy consumption ${ }^{[22]}$.

What seems to be critical here is the focus solely on the technical aspect of energy efficiency management. This concentration has focused on the specific design considerations when building a ship and implementing a supervisory and management system on energy use, especially of the fleet ${ }^{[9]}$.

This point of view can be led to other issues being overlooked or even neglected aspects and topics such as the workforce's role or even gender in energy efficiency management ${ }^{[9]}$.

\section{Analysis by Using Five P's of Sustainable Development}

This section examines the role of key players in Oman's maritime industry including, Oman Fisheries Company and Oman Shipping Company, in five key areas and indicators in sustainable development goals, including people, planet, peace, prosperity, and partnership.

Achieving sustainable development goals in the maritime industry will certainly not be achieved unless all stakeholders are directly or indirectly involved. Where sustainable development goals are accepted, in the form of a blueprint, including a set of goals designed in different parts, synergy and stakeholder engagement can be very useful because of the shared purpose.

\subsection{People}

As an essential part of the food chain, fisheries play a vital role in maintaining healthy nutrition and reducing hunger. Oman Fisheries, both domestically and regionally and internationally, have been instrumental in reducing 
hunger by having a significant market share of fish and related products. The emphasis on food and health under its goals reflects its commitment to public health. Providing healthy, appropriate, and quality food is one indicator of a sustainable society ${ }^{[21]}$.

One of the hallmarks of any underdeveloped country can be the country's high poverty rate. As a result of inadequate explanations of wealth, class distinctions and gap, and lack of access to adequate food, growing poverty is moving towards deepening.

Key factors in reducing poverty are provided equal opportunities and creating appropriate employment opportunities, and the abundance and availability of adequate food. Oman Fisheries have helped significantly reduce poverty rates both domestically and internationally, by providing a suitable environment for the supply and distribution of sufficient food, both for domestic consumption and to meet some international food needs ${ }^{[21]}$.

The Oman Shipping Company has been instrumental in expanding domestic trade and creating new job opportunities by creating a secure business route and expanding trade internationally ${ }^{[26]}$.

The expansion of commerce has enabled the expansion of the logistics and commerce sector, industries, and related small businesses. The development of roads, residences, warehouses, out-of-doors restaurants, repair shops, and even the development of these required training centers are only part of this activated chain. In other words, the activation and expansion of Shipping, both directly and indirectly, can lead to sustainable development.

\subsection{Planet}

The Oman Fisheries Company considers itself responsible for the conservation and protection of the environment and the prevention of pollution of the seas. This company has also allocated a portion of its profits to the marine environment and upgraded its safety knowledge. The company focuses on preserving the marine environment and clean water, focusing on preserving marine resources and healthy food. In the company's vision, the emphasis is on the sustainability of the fisheries' environment $^{[21]}$.

The country approved and implemented a law prohibiting trawl fishing in 2011 to protect the marine environment and its resources ${ }^{[34]}$.

As stated, in 2019, the Oman Shipping Company ordered the construction of three very large tanker vessels to the Daewoo Shipbuilding Company ${ }^{[24]}$. A few months later, the company commissioned two more eco-friendly tanker ships with the Daewoo Shipbuilding Company ${ }^{[27]}$.

What was highlighted in these orders was the emphasis on environmentally-friendly, eco-friendly, which demonstrates the company's strong commitment to protecting the environment through modern shipbuilding technologies. The company also emphasizes the strict implementation of International Maritime Law and Regulations in marine environment protection as a committed member of the global maritime community ${ }^{[26]}$.

\subsection{Peace}

One of the most critical indicators in the field of peace is the security in that community. The security of each community reflects people's attitudes in societies in the field of ethical, social, and economic indicators. Poverty, unemployment, and illiteracy are threats to any country's security that can lead to instability and conflict and are one of the biggest obstacles to sustainable growth.

Oman's Fisheries Company has had a significant impact on the development of peace by affecting various sectors and ways of affecting the country's security. Creating job opportunities and sustained employment has reduced the poverty rate and, as a result, increased community mental health and well-being. Also, proper and healthy nutrition has enhanced security ${ }^{[21]}$.

The development of a skilled and efficient workforce, which contributes to the growth of literacy and expertise, has added to the promotion of security and, ultimately, sustainable peace. One of the goals of Oman Shipping Company is to provide safe and reliable service to all customers ${ }^{[26]}$.

Due to the volume of cargo movement and other required products of the country, which is mostly done by the company's fleet, it has had a significant impact on supplying the country's people with needs in the field of import and export, as well as providing economic security for the people. Oman Shipping Company is one of the most active companies in sustainable peace.

\subsection{Prosperity}

The Oman Fisheries Company has been able, by employing a large number of young people, to play an important role in reducing the unemployment rate and thereby increasing people's well-being ${ }^{[21]}$.

The existence of this industry and the creation of a distribution chain have created many jobs, directly and indirectly, in the field, leading to increased levels of public welfare ${ }^{[21]}$. On the other hand, with the optimization of this trade and new technologies in the production and supply of fishery products, energy consumption has improved and decreased compared to traditional systems.

Also, the reduction of energy consumption and the use 
of new technologies have reduced the price of finished goods and, consequently, increased the people's purchasing power, which is a move forward in the sustainable prosperity of the people ${ }^{[26]}$.

The Oman Shipping Company has a well-planned program to recruit labor from the Omani youth. This job is equally available to all, regardless of gender ${ }^{[26]}$. Providing these enduring job opportunities enhances happiness and ultimately sustained prosperity.

Oman Shipping Company has provided a scholarship to those interested in studying marine engineering and nautical science. In addition to its support for the maritime industry, the company has also provided an opportunity for undergraduates to pursue an internship on the company's fleet ${ }^{[26]}$.

This excellent performance has not only increased the sense of hope and satisfaction among young people but has also made a positive step towards achieving sustainable development goals.

\subsection{Partnership}

The Oman Fisheries Company has one of the best partnership models in sustainable development with the granting of shares to fishers. This decision led them to increase their level of responsibility as they participate in fisheries. The company is also a reliable trading partner for other countries by exporting fish and other fishery products to more than 55 countries. Considering part of its profits in creating new job opportunities for fishermen, coastal women, and new markets, it has also increased the level of participation at the domestic level ${ }^{[26]}$.

The Oman Shipping Company is moving towards sustainable development by providing the appropriate infrastructure and facilities needed by domestic, regional, and international maritime transport industries. This partnership encompasses a wide range of industries. The Oman Shipping Company is equipped with its maritime fleet, in various maritime shipping areas, including tankers, containers, bulk carriers, General Cargoes, and chemical tankers; it has been able to play a unique role in the development and stability of this partnership by providing safe and orderly services ${ }^{[26]}$.

Key partners in domestic supply include the Orpic Company (the largest petrochemical company in Oman), Sohar Aluminium, and Oman LNG Company. Regional offerings include Indian Sail Company active in Steel Trading and internationally includes Shell Oil Co., BP Oil Co., and Brazilian Vale Company active in Mining Trading ${ }^{[26]}$.

\section{Conclusions}

In studying the marine industry of Oman, in line with Sustainable Development Goal \# 7, and the five relevant and influential areas of this document, namely the people, the planet, peace, prosperity, and partnership, seem to be a distinct and well-structured program at different levels that demonstrates national determination in the right direction towards development goals.

Sectors and stakeholders of the country's maritime industry are moving alongside each other in pursuit of these goals, along with the synergy and overlap, which is a good sign of achieving sustainable development goals.

Meanwhile, some areas and sectors of the maritime industry that have the potential to achieve sustainable development goals have not been addressed. Among these areas can be mentioned, ocean energy, aquaculture, coastal tourism, marine biotechnology, renewable energy use in ports and ships, deep-sea mining.

On the other hand, annual and documented reports that specifically address sustainable development goals have not been published by companies involved in the maritime industry. These reports can lead to precise targeting, benchmarking, analysis of current conditions, and explaining new strategies and ways to move smarter on the path to development goals.

One of the appropriate approaches in sustainable development could be modeling plans and methods being implemented by other countries.

Finally, although Oman is on the right track towards development goals, it can accelerate and create effective solutions by focusing on new technologies and innovative designs and more productive industry linkages with science centers.

\section{References}

[1] Blue Generation Project, n.d. Retrieved from https:// www.bluegeneration.org/index.php/en/component/ content/article/2-uncategorised/25-about-blue-generation-project

[2] Climate,n.d..Retrieved from http://www.sustainableoman.com/legislation/\#Climate

[3] DNV-GL, Sustainable Development Goals: Exploring Maritime Opportunities, 2017. Retrieved from https://rederi.no/globalassets/dokumenter-en/all/fagomrader/smi/dnv-gl-sdg-maritime-report.pdf

[4] GMN, The Global MTCC Network, about GMN, Energy efficiency is shippig-why it matters, N.d. Retrieved from https:/gmn.imo.org/about-gmn/

[5] Grațiela B., Sustainable Maritime Transportation System in European Union, 2019. Retrieved from 
http://annals.cmu-edu.eu/index.php/cmuannals/article/view/45/13

[6] ICMET. International conference on marine engineering and technology. Military technological college. Muscat, Oman, 2019, November 5-7. Retrieved from https://icmetoman.com/

[7] International Maritime Organization. Energy Efficiency Measures, 2011. Retrieved from http://www. imo.org/en/OurWork/Environment/PollutionPrevention/AirPollution/Pages/Technical-and-Operational-Measures.aspx

[8] International Maritime Organization. IMO and the Sustainable Development Goals, 2019. Retrieved from http://www.imo.org/en/MediaCentre/HotTopics/Pages/SustainableDevelopmentGoals.aspx

[9] Kitada M, Rabo K, Toua O, Nervale T. The Role of Maritime Transport from the Perspective of Energy and Gender: The Case of the Pacific Islands. In: Ölçer AI, Kitada M, Dalaklis D, Ballini F (eds) Trends and challenges in maritime energy management, vol 6 . WMU studies in maritime affairs. Springer, 2018, pp 367-380.

[10] Koilo V., Energy efficiency and green solutions in sustainable development: evidence from the Norwegian maritime industry, 2020. Retrieved from https:// search.proquest.com/openview/9b23e25e6944ab$700 \mathrm{~d} 1 \mathrm{abc} 4 \mathrm{c} 7 \mathrm{~d} 624217 / 1$ ?pq-origsite $=$ gscholar $\& \mathrm{c}-$ $\mathrm{bl}=4368393$

[11] Maersk.2020 Sustainability Report, 2021. Retrieved from https://www.google.com/ url s $\mathrm{s}=\mathrm{t} \& \mathrm{rct}=\mathrm{j} \& \mathrm{q}=\& \mathrm{esrc}=\mathrm{s} \&$ source $=\mathrm{web} \& \mathrm{c}-$ $\mathrm{d}=\& \mathrm{cad}=\mathrm{rja} \& \mathrm{uact}=8 \& \mathrm{ved}=2 \mathrm{ahUKEw}$ ifw 4jNz6nvAhWIQUEAHbyPBR0QFjAFegQIDhAD\&url=https\%3 A \%2F\%2Fwww.maersk. com $\% 2 \mathrm{~F} \sim \% 2 \mathrm{Fmedia}$ sc $9 \% 2 \mathrm{Fmaersk} \%$ 2 Fabout $\% 2$ Ffiles $\% 2$ Fsustainability $\% 2$ Fsustainability-reports\%2Fapmm-sustainability-report-2020-a3. pdf\&usg=AOvVaw0e5frgb-wsPB6vNjv0ZGmf

[12] Maersk. Maersk and the Sustainable Development Goals, 2017. Retrieved from

https://www.maersk.com >03-apmm-maersk-sdgdocument-jan2017-v2

[13] Malallah H E. The Contributions of the Islamic Culture for the Maritime Silk Route. International Expedition of "the Islamic Culture along the Coast of China. Quanzhou, China, 1994. Retrieved from https://en.unesco.org/silkroad/sites/silkroad/files/ knowledge-bank article/the_contributions_of_the islamic_culture_for_the_maritime_silk_route.pdf

[14] Mediterranean Shipping Company, 2018 Sustainability Report, 2019. Retrieved from https://www.msc. $\mathrm{com} / \mathrm{mmr} /$ news/2019-october/msc-publishes-annu- al-sustainability-report-2018?lang=ja-jp

[15] Medhat G. Here's Why Omanis Are One of the Greatest Shipbuilders in the World, 2017. Retrieved from https://theculturetrip.com/middle-east/oman/ articles/heres-why-omanis-are-one-of-the-greatestshipbuilders-in-the-world/

[16] Ministry of Environment and Climate Affairs. Overview Ministry of Environment and Climate Affairs, n.d. Retrieved from https://omanportal.gov.om/wps/ $\mathrm{wcm} /$ connect/en/site/home/gov/gov1/gov5governmentorganizations/moeca/moe

[17] National Ferries Company, 2019. Retrieved from http://www.nfc.om/AboutUs

[18] Oman dry-dock, 2019a. Retrieved from http://www. omandrydock.com/

[19] Oman dry-dock, 2019b. Retrieved from https://www. linkedin.com/company/oman-drydock-company

[20] Oman, November,1,2019.Retrieved from https:// en.wikipedia.org/wiki/Oman

[21] Oman Fisheries Company, Oman fisheries CO.S.A.O.G, twenty-ninth annual report 2018. Retrieved from http://omanfisheries.com/annual-reports/

[22] Ölçer A.I., Kitada M., Dalaklis D., Ballini F., development of a holistic maritime energy management programme at the postgraduate level: the case of WMU. Conference, Valencia, Spain, March 6-8, 2017. Retrieved from https://www.academia. edu/31912405/DEVELOPMENT_OF_A_HOLISTIC_MARITIME_ENERGY_MANAGEMENT_ PROGRAMME_AT_THE_POSTGRADUATE_ LEVEL_THE_CASE_OF_WMU

[23] Oman Ministry of transport and communication. (2018). Oman ministry of transport annual report 2018. Retrieved from https://motc.gov.om

[24] Oman Observer, Oman Shipping to invest in 3 new VLCCs. Oman Observer, June 26, 2019. Retrieved from https://www.omanobserver.om/oman-shippingto-invest-in-3-new-vlccs/

[25] Oman-population, N.d. Retrieved from https://www. worldometers.info/world-population/oman-population/

[26] Oman Shipping Company, N.d. Retrieved from https://www.omanship.co.om/About/About-OSC

[27] Prabhu C., Oman Shipping inks deal for two new eco-friendly crude carriers. Oman Observer, January 18, 2019.Retrieved from https://www.omanobserver.om/oman-shipping-inks-deal-for-two-new-ecofriendly-crude-carriers/

[28] Supreme Council for Planning, First Voluntary National Review of The Sultanate of Oman 2019. Retrieved from https://www.scp.gov.om/PDF/Sustainable.pdf 
[29] Sustainability, Shipping's critical role in meeting many of the UN SDGs, 2018. Retrieved from https:// safety4sea.com/cm-shippings-critical-role-in-meeting-many-of-the-un-sdgs/

[30] Times News Service, Oman to have best growth rate in GCC in 2020, says World Bank. Times of Oman, May, 18, 2019. Retrieved from https://timesofoman. com/article/1314904/Oman/Oman-to-have-bestgrowth-rate-in-GCC-in-2020-says-World-Bank

[31] United Nations General Assembly Resolution, Transforming our world: the 2030 Agenda for Sustainable Development, A/RES/70/1, 2015. Retrieved from https://www.un.org/ga/search/view_doc.asp?symbol$=\mathrm{A} / \mathrm{RES} / 70 / 1 \&$ Lang $=\mathrm{E}$

[32] Wahlen C.B., Five Pacific Countries Launch Partnership to Decarbonize Shipping Industry. SDG Knowledge Hub, October, 3, 2019.Retrieved from https:// sdg.iisd.org/news/five-pacific-countries-launch-partnership-to-decarbonize-shipping-industry/

[33] Wang X., Yuen K.F., Wong Y.D., Li K.X. How can the maritime industry meet Sustainable Development Goals? An analysis of sustainability reports from the social entrepreneurship perspective, 2019. Retrieved from https://www.researchgate.net/publication/337019080_How_can_the maritime_industry_meet_Sustainable_Development_Goals_An analysis_of_sustainability_reports_from_the_social_ entrepreneurship_perspective

[34] World Bank, Sustainable Management of the Fisheries Sector in Oman: A Vision for Shared Prosperity, 2015. Retrieved from https://www.worldbank.org/ en/country/gcc/publication/sustainable-managementof-the-fisheries-sector-in-oman-a-vision-for-sharedprosperity

[35] World Ports Sustainability Program, World Ports Sustainability Report 2020, 2021. Retrieved from https://sustainableworldports.org/wp-content/uploads/WORLD-PORTS-SUSTAINABILITY-REPORT-2020-FIN.pdf 